\title{
Changes in the Soil Cover under the Impact of Short-Term Climate Fluctuations
}

\author{
L. G. Smirnova ${ }^{a}$ * , Y. G. Chendev ${ }^{a}$, N. S. Kukharuk ${ }^{a}$, A. G. Narozhnaya ${ }^{a}$, \\ S. A. Kukharuk ${ }^{a}$, and G. V. Smirnov ${ }^{a}$ \\ ${ }^{a}$ Belgorod State National Research University, Belgorod, 308015 Russia \\ *e-mail: lidya.smirnova@yandex.ru
}

Received October 1, 2018; revised December 14, 2018; accepted December 26, 2018

\begin{abstract}
The climate of the 1950s-1990s in the center of the Russian Plain was characterized by the alternation of cool-wet and warm-dry periods, which is confirmed by hydrothermal coefficients. The studies in the south of the forest-steppe of the Central Russian Upland (Belgorod oblast) based on the geoinformation analysis of different-time soil maps have revealed regular changes in the boundaries of soil areas of automorphic chernozems (Chernozems) related to these intra-century climatic cycles. The transformed chernozems area was 125790 ha (38.5\%). In general, 61.5\% (328885 ha) of soil areas in the studied region remained unchanged. The response of the soil cover was indicated by behavior of carbonates and leaching. It has been revealed that with increase of hydrothermal coefficient by more than 0.2 , the effervescence line in chernozems is oscillating, which results in a change in the taxonomic position of soils at the subtype level.
\end{abstract}

Keywords: chernozems, forest-steppe, Central Russian Upland, climate change, GIS method, vector maps

DOI: $10.1134 / \mathrm{S} 1064229319070111$

\section{INTRODUCTION}

The survey of climate changes at numerous meteorological stations confirms the widely spread idea that the climate parameters are not constant, and are subject to particular fluctuations $[6,7,9,12,14]$. The studies enable to determine the main climatic trend, consisting in an increase in the air temperature and affecting the duration of meteorological seasons [5, 8].

A special attention is paid to the studies, which are targeted to the impact of climate changes on land ecosystems and their biodiversity and productivity $[10,14$, 18]. The inter-century climatic cycles are characterized by a wave-like dynamics, which affects the soil cover status [16]. Carbonate accumulation and leaching are the most variable soil-genetic parameters $[3,4$, $11,15]$. The carbonate status of chernozems is considered to be a sensitive indicator of climate fluctuations; most of its parameters quickly respond to climatic fluctuations, which may be recorded in short soil chronoseries, where the periods between the points (soils) are 25-50-year-long [17].

Some authors $[2,13]$ also discuss the effect of significant precipitation in combination with biologically active temperatures on variations in the carbonate profile and a number of other soil morphological parameters. However, the data on the effect of intercentury climatic cycles on soils and soil cover are insufficient. It is reasonable to solve these problems using geoinformation systems making it possible to trace changes in the boundaries and taxonomic position of soils mapped during large-scale soil surveys.

The aim of this work was to reveal the response of the soil cover to short-period climatic fluctuations on the basis of the analysis of large-scale soil maps compiled in different times using GIS technologies.

The tasks of the study included: (1) the analysis of meteorological features of the intra-century climatic cycle, corresponding to the periods of soil surveys in the 1970s and 1990s; (2) revealing of the response of automorphic chernozems (Chernozems) of the southern forest-steppe to climatic fluctuations with the use of GIS technologies and on the basis of data of different-time large-scale soil mapping.

Ecosystems have to adapt to various kinds of impact of fluctuating climate. Therefore, it is very important to analyze the real changes in the soil cover pattern, primarily on the basis of available data, and to forecast them in future. The concept of sustainable development, which is formulated by society for the twenty-first century, can be only realized, if these problems are solved.

\section{OBJECTS AND METHODS}

To solve the tasks, we used methodological approaches for processing different-time large-scale soil maps of the Shebekinsk district as the test object [16]. The technology then was used for the adjacent 


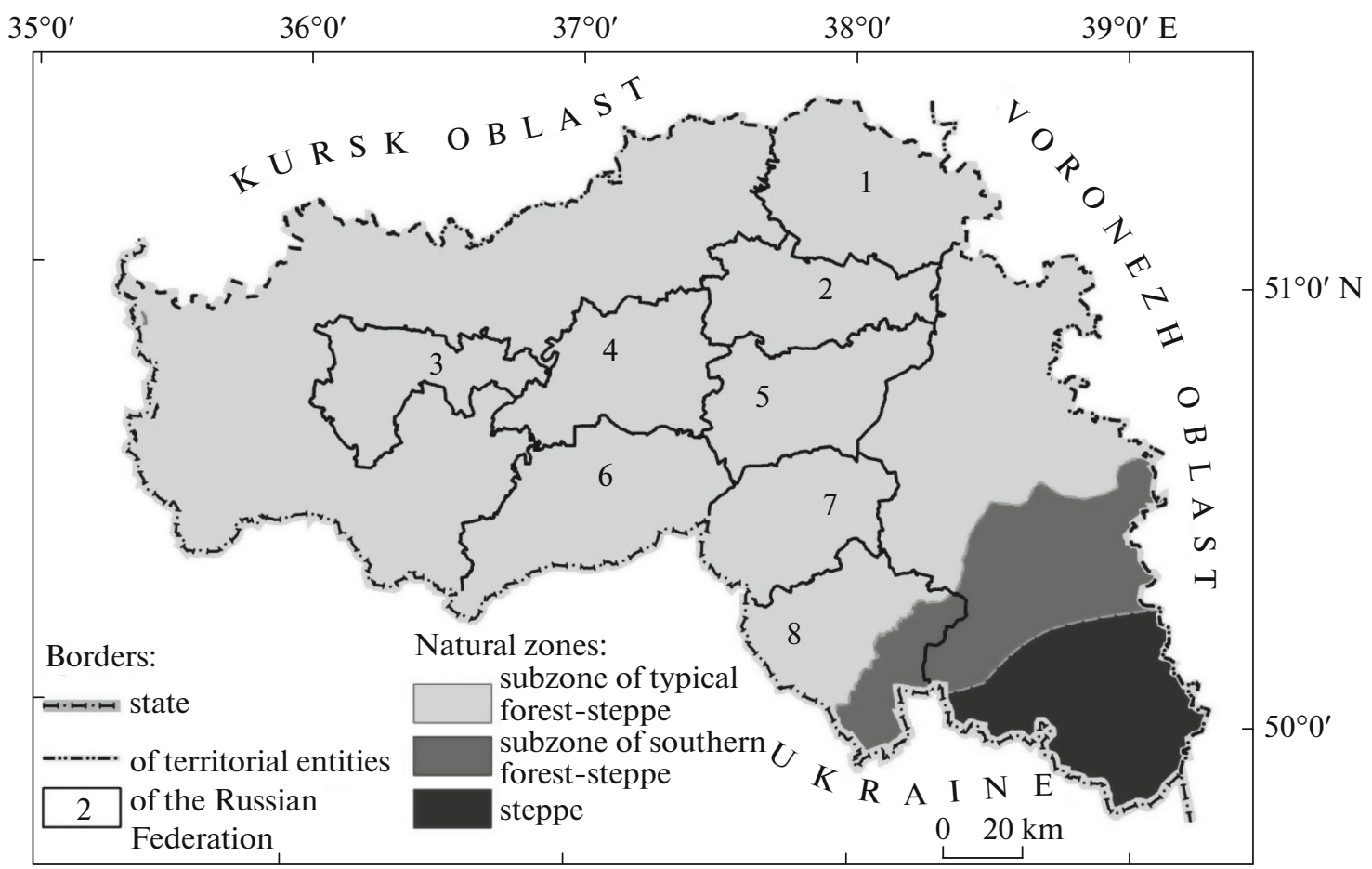

Fig. 1. The area of Belgorod oblast and districts studied: 1-Starooskol'sk urban okrug, 2-Chernyansk district, 3-Yakovlevsk district, 4-Korochansk district, 5-Novooskol'sk district, 6-Shebekinsk district, 7-Volokonovsk district, and 8-Valuisk district.

Chernyansk, Novooskol'sk, Yakovlevsk, Korochansk, Valuisk, and Volokonovsk districts and Starooskol'sk urban okrug (Fig. 1).

The soil surveys in Belgorod oblast were performed twice: in the early 1970s and in the 1990s. Their results were taken in the archives of the Federal Service for State Registration, Cadaster, and Cartography (Rosreestr). These surveys were performed by the State Institute for Land Management (Giprozem). The period between them in different districts of the oblast averaged twenty years. Large-scale $(1: 10000)$ soil maps of farms were used to compile regional soil maps, the scale of which was decreased to $1: 50000$. An algorithm for analyzing the materials of repeated soil surveys (Fig. 2) was proposed to study the role of intra-century climatic variability.

The soil maps of the districts studied at the two surveys were digitized in the ArcMap program with the use of the ArcGIS geoinformation software. The constructed databases of soil areas were used to reveal the changes in the soil cover over the period between the surveys. The digitized soil maps were superimposed on the topographic base to identify soil areas allocated to automorphic sites and gentle slopes $\left(1^{\circ}-3^{\circ}\right)$ and were referred to satellite images in the ArcGIS program. The best adjustment of soil areas was achieved (the mean square error at the cell size of $10 \mathrm{~m}$ and the affine transformation averaged $7 \mathrm{~m}$ for all maps). The erosion network was mapped on the basis of the Shuttle Radar Topography Mission (SRTM) data, and maps of slope gradients and aspects were vectorized. As a result of using the Intersection function, they were combined into one file, containing the data on soil transformation, which enabled to determine soil areas in different combinations. River basins of the fifthseven orders were assigned to the right or left slope, using a topographical map $(1: 10000)$, and the data were inserted into the attribute table. The frequency tool was used to compile reports on soil areas on slopes of different aspects and river banks. The tool enabled to classify the changed soils with respect to the transformation type and slope aspect, or river bank and to obtain their total areas. The Select by Attributes tool was then used to obtain data necessary for the analysis.

To characterize the meteorological features of the studied area, we collected data on climatic parameters (precipitation and mean temperatures) of Belgorod (the meteorological stations of Gotnya, Bogoroditskoe-Fenino, and Valuiki) and adjacent areas (the cities of Kalach, Voronezh, Kursk, and Khar'kov) and used the archived data of the State data Foundation on the environment status. We calculated the hydrothermal coefficient for the periods of soil surveys. The best method of the interpolation of climatic parameters (precipitation, mean annual temperature, and hydrothermal coefficient) was selected, using geostatistical operations in the ArcGIS 10.2 software package. The errors were the smallest, when we used radial basis functions (completely regularized spline). The resulting predictive maps were rasterized for further analysis. 


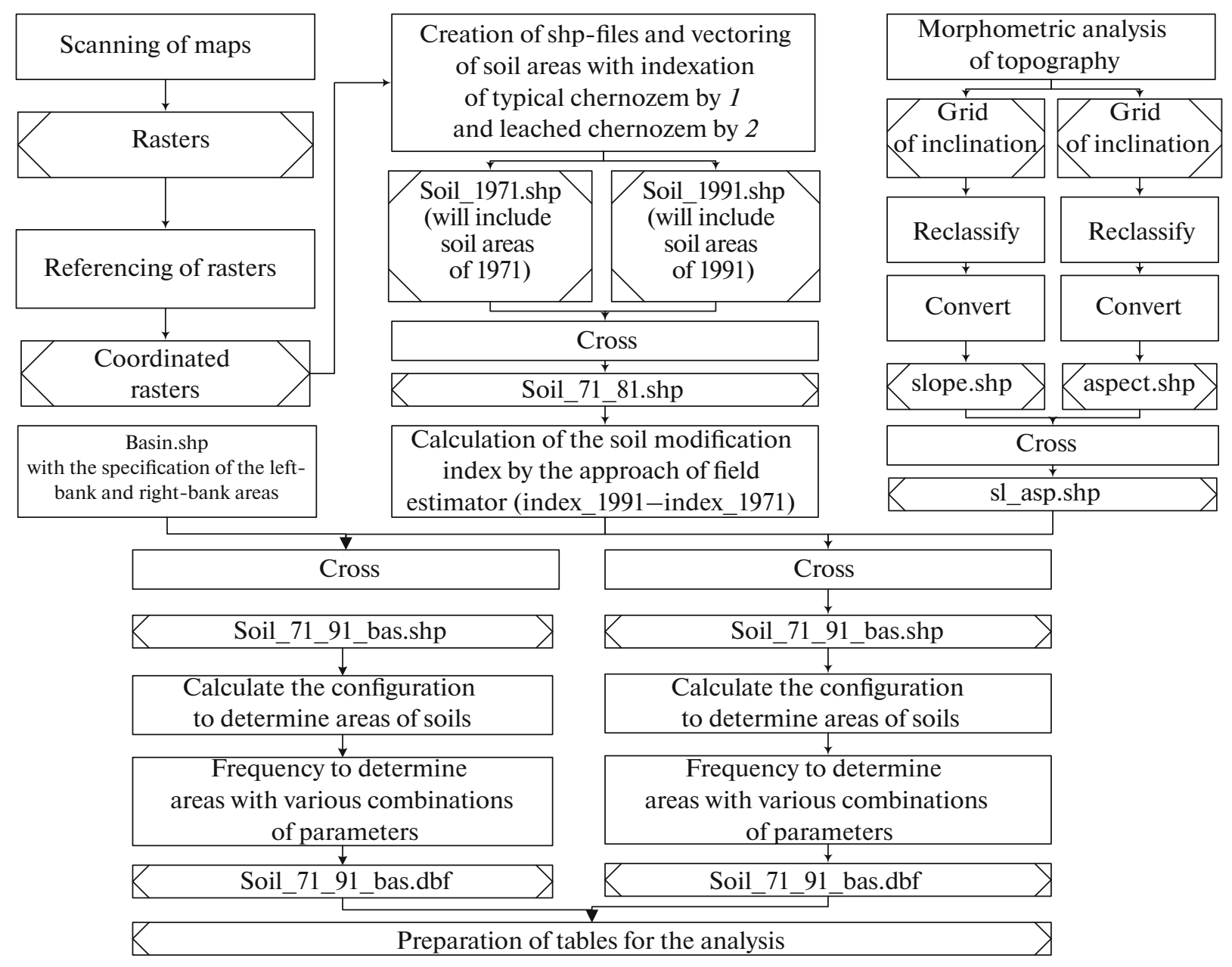

Fig. 2. Algorithm of analysis of data of repeated soil surveys to substantiate the role of intra-century climatic fluctuations.

\section{RESULTS AND DISCUSSION}

The analysis of meteorological features of the inter-century climatic cycle prior to the first soil survey (1951-1970) has shown that the hydrothermal coefficient (HTC) in the survey area varied from 1.1 to 0.8 in the north-south direction (Fig. 3). The mean annual air temperature then was below the average. In the period between the surveys (1971-1990), it was in general above the climatic norm. The precipitation displayed a trend towards increase. The minimum in the series of observations was recorded in 1975 (396 mm), and then, their amount increased to $486 \mathrm{~mm}$ in 1984 and to $497 \mathrm{~mm}$ in 1991. This trend was in general typical for the studied area according to the HTC, which increased to $1.1-1.33$ in that period as compared to the period prior to $1971(0.8-1.1)$.

The mean annual precipitation is more than $550 \mathrm{~mm}$ in the west of the oblast (in the north of Yakovlevsk district) and moderate (from 500 to $550 \mathrm{~mm}$ ) in its southwestern part. Most of Shebekinsk and Korochansk districts are assigned to the zone of moderate precipitation $(500-550 \mathrm{~mm})$. The maximal precipita- tion (more than $550 \mathrm{~mm}$ ) is typical for a significant part of the studied area: for Starooskol'sk, Chernyansk, Novooskol'sk, Valuisk, and Volokonovsk districts.

The mean annual temperatures are characterized by a particular regularity. There is a gradual increase in temperature from the northwest to the southeast. Chernyansk, Korochansk, and the northwest of Starooskol'sk districts are assigned to the area of mean annual temperatures in the range of $6.6-7.0^{\circ} \mathrm{C}$. The zone with the temperatures from 7.1 to $7.5^{\circ} \mathrm{C}$ includes Yakovlevsk, Shebekinsk, Novooskol'sk, and parts of Valuisk and Korochansk districts. The mean annual temperature is maximal in Valuisk and Volokonovsk districts (more than $8.5^{\circ} \mathrm{C}$ ).

We have analyzed the soil cover of the studied area in the period between the first and second large-scale soil surveys in Valuisk, Yakovlevsk, Starooskol'sk, and Volokonovsk districts of Belgorod oblast. It has been revealed that typical chernozems (Haplic Chernozems (Loamy, Pachic)) have changed into leached chernozems (Luvic Chernozems (Loamic, Pachic)) mainly on northern and eastern slopes, which was related to 


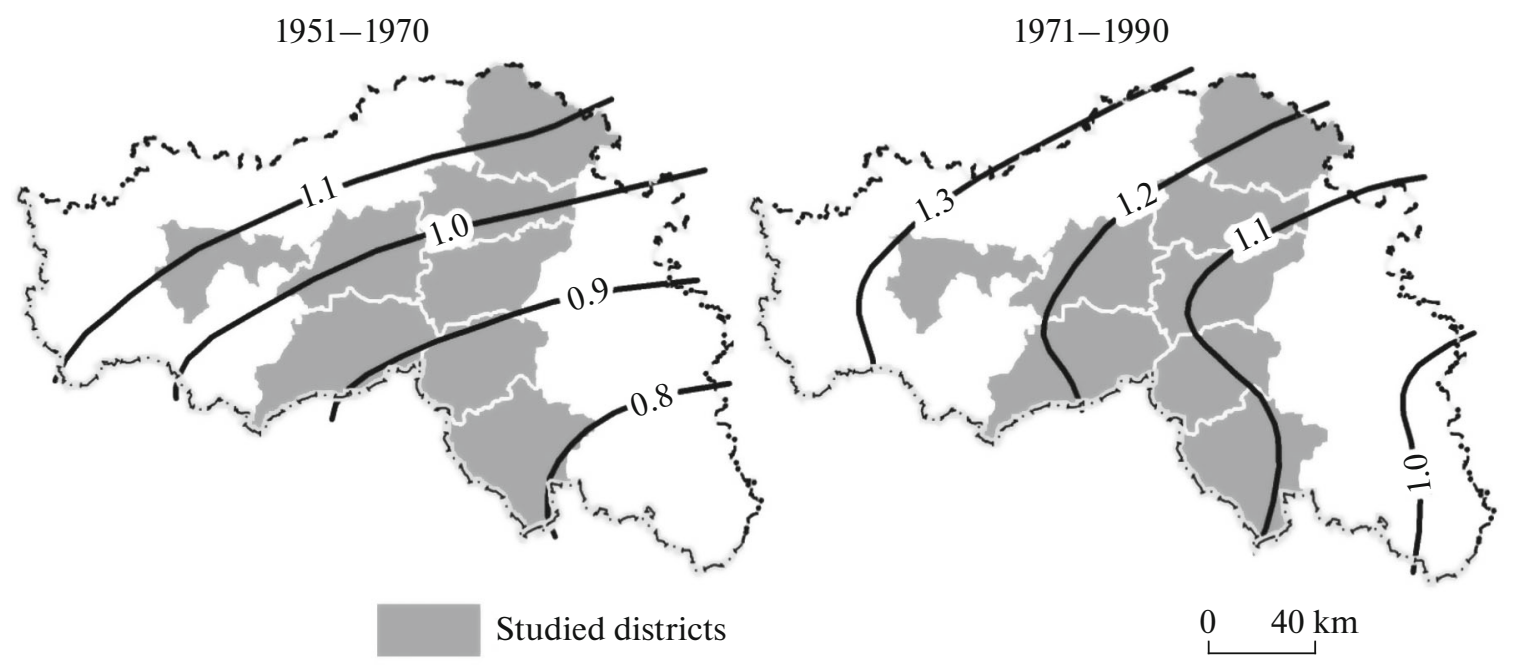

Fig. 3. Hydrothermal coefficient in the periods prior to the first (1951-1970) and the second (1971-1990) soil surveys.

the dynamics of carbonates in the soil profile. The period of 1971-1991 was characterized by higher HTC (by 0.26 on the average) than in the previous period (Fig. 3). The highest humidity was seen in southern districts (Shebekinsk, Korochansk, Valuisk, and Volokonovsk), in which the HTC increased by $0.25-$ 0.37 in comparison with the preceding survey period. According to soil maps, significant areas of typical chernozems in these districts were transformed into leached chernozems. The hypothesis that the effervescence line in chernozems varies under the conditions of increasing HTC and results in a change in the taxonomic position of soils at the subtype level is confirmed, only if the HTC rises more than by 0.2 . The data obtained has shown that the effervescence line in typical chernozems drops in seven of the eight studied districts (except for Starooskol'sk urban okrug).

The spatial transformation of soil areas of the studied districts of Belgorod oblast is given in Fig. 4. The visualization of the obtained cartographic material enabled to reveal some regularities in the distribution pattern of the studied soil areas. The background is formed by untransformed subtypes of chernozems. The soil cover is in general resistant to short-term climatic fluctuations. However, in Valuisk, Yakovlevsk, Volokonovsk, and Chernyansk districts, the transformation of some soil areas is significant. There is an increase in the areas, where typical chernozems (Haplic Chernozems) are transformed into leached chernozems (Luvic Chernozems). They form large massifs. In the northern and central parts (in Korochansk, Shebekinsk, Starooskol'sk, and Novooskol'sk districts), typical chernozems are also replaced by leached chernozems, but their portion is significantly lower. The ArcGIS program makes it possible to quantify the changed soil areas.

The results of processing of cartographic materials in ArcGIS program for districts of the oblast, which were covered by soil surveys in the 1970s and 1990s, are given in Table 1. It has been revealed that about one third of the soil areas in the districts studied underwent changes $(38.5 \%, 125790 \mathrm{ha})$, and $61.5 \%$ (328885 ha) remained unchanged. The area of transformed soils was the largest in Valuisk district (19080 ha) and the smallest in Starooskol'sk district (10020 ha).

The areas of changed (Luvic Chernozems) and unchanged chernozems (are given in brackets) in the studied districts, including the control object (Shebekinsk district), were: 19080 ha (3088 ha) in Valuisk district; 14815 ha (24400 ha) in Novooskol'sk district; 13480 ha (30898 ha) in Chernyansk district; 20035 ha (18733 ha) in Korochansk district; 14113 ha (35241 ha) in Shebekinsk district; and 10020 ha (37890 ha) in Starooskol'sk district. The portion of transformed soils ranges from 20 to $86 \%$ in relation to the untransformed ones.

The area of transformed leached chernozems in large-scale maps of Valuisk district is by 11244 ha greater than the area of typical chernozems. The analysis of the soil cover in other districts shows that this trend is preserved (but to a smaller extent) in Yakovlevsk (5003 ha), Volokonovsk (2778 ha), and Chernyansk (2144 ha) districts. In general, the studied oblast is characterized by an increase in the area of leached chernozems by 21150 ha.

The change in soil areas was the most intensive on the left banks of the Koren', Korocha, Oskol, and Nezhegol' rivers. The area of changed soils occupied by leached chernozems was 2144 ha in Chernyansk district, 2118 ha in Korochansk district, 1619 ha in Shebekinsk district, and only 583 ha in Novooskol'sk district.

The hypothesis is also confirmed for the Volokonovsk district, where there is an increase in the areas of leached chernozems on the background of a drop in the area of typical chernozems, which comprises 2778 ha. 


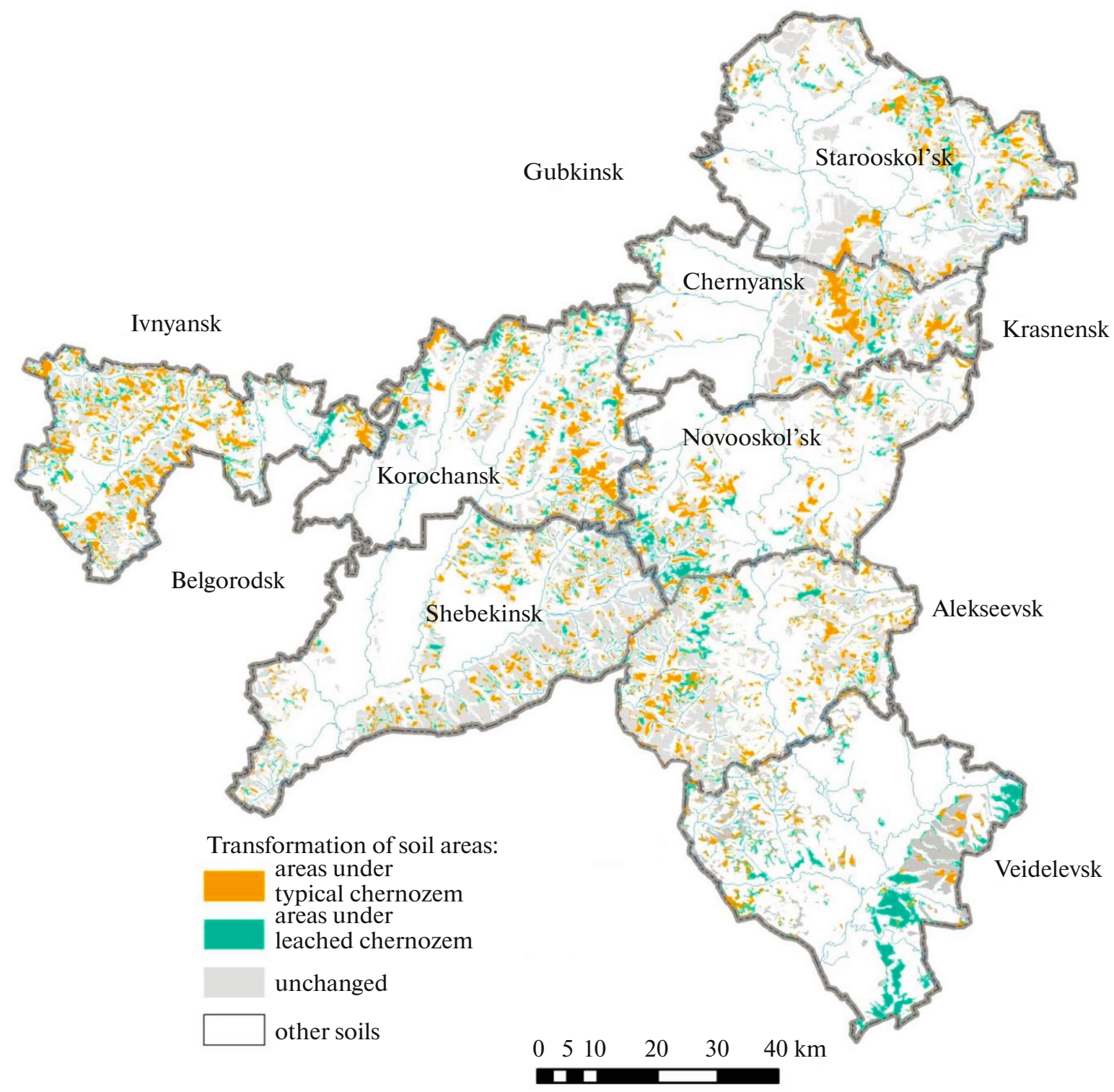

Fig. 4. Spatial transformation of soil areas in the studied districts of Belgorod oblast.

The spatial analysis shows that the transformation of typical chernozems into leached ones in the smallest in Starooskol'sk district.

The analysis of allocation of the soils to slopes of various aspects (Table 2) shows that areas of changed leached chernozems are the greatest on the northern slopes (33647 ha in total) and are the smallest on the eastern slopes (7666 ha).

In general, the studied districts are characterized by a significant increase in the areas of leached chernozems in automorphic positions and on gentle slopes (to $3^{\circ}$ ).

The hypothesis that the dynamics of the effervescence line in chernozems occurs under the conditions of cyclogenesis and results in a change in the taxonomic position of soils at the subtype level is only con- firmed in some districts. The data obtained show that the lowering of the effervescence line is the most pronounced in typical chernozems in Korochansk, Novooskol'sk, Volokonovsk, and Valuisk districts.

As a result of the research, we have prepared the inventory of large-scale maps and soil descriptions of various periods of soil survey, corresponding to the periods of various phases of the inter-century helioclimatic cycles. An electronic database of soil areas of the studied region was constructed. It should be used to identify the transformation of the system of soil areas in maps of different periods of soil survey of the southern forest-steppe of the Central Russian Upland, as well as to store the basic soil and climatic layers as grids, where each cell bears particular information. The database may be used to obtain the information 
Table 1. Changes in soil areas (ha) according to the data of two large-scale soil surveys

\begin{tabular}{l|c|c|c|c}
\hline \multicolumn{1}{c|}{ District } & $\begin{array}{c}\text { Areas of leached } \\
\text { chernozems }\end{array}$ & $\begin{array}{c}\text { Areas of typical } \\
\text { chernozems }\end{array}$ & $\begin{array}{c}\text { Total area of soils } \\
\text { studied }\end{array}$ \\
\hline Starooskol'sk & 2481 & 7539 & 37890 & 47910 \\
Chernyansk & 7811 & 5667 & 30898 & 44376 \\
Yakovlevsk & 12343 & 7340 & 22022 & 41705 \\
Korochansk & 11072 & 8955 & 18733 & 38768 \\
Novooskol'sk & 7659 & 7156 & 24400 & 39215 \\
Shebekinsk & 7866 & 6247 & 35241 & 49354 \\
Valuisk & 15162 & 3918 & 3088 & 22168 \\
Volokonovsk & 8671 & 5893 & 30823 & 45387 \\
Total for districts & 73865 & 52715 & 203095 & 328883 \\
Portion of studied soils, \% & 19.7 & 18.8 & 61.5 & 100 \\
\hline
\end{tabular}

Table 2. Dynamics of areas of chernozems (typical are above the line and leached are under the line) in automorphic positions and on gentle slopes $\left(1^{\circ}-3^{\circ}\right)$ of different aspects in Belgorod oblast

\begin{tabular}{|c|c|c|c|c|c|c|}
\hline \multirow{3}{*}{ District } & \multicolumn{4}{|c|}{ Aspect } & \multirow{2}{*}{\multicolumn{2}{|c|}{$\begin{array}{l}\text { Unchanged, portion of the } \\
\text { total area }\end{array}$}} \\
\hline & north & east & south & west & & \\
\hline & \multicolumn{4}{|c|}{ ha } & ha & $\%$ \\
\hline Starooskol'sk & $710 / 2840$ & $533 / 948$ & $509 / 2815$ & $729 / 936$ & 37890 & 79.1 \\
\hline Chernyansk & $3745 / 2520$ & $1053 / 749$ & $1917 / 1752$ & $1096 / 646$ & 30898 & 69.6 \\
\hline Yakovlevsk & $5929 / 3212$ & $1247 / 595$ & $3919 / 2511$ & $1248 / 1022$ & 22022 & 52.8 \\
\hline Korochansk & $4456 / 3709$ & $1447 / 938$ & $3994 / 3143$ & $1175 / 1165$ & 18733 & 48.3 \\
\hline Novooskol'sk & $3710 / 3327$ & $646 / 748$ & $2467 / 2302$ & $836 / 779$ & 24400 & 62.2 \\
\hline Shebekinsk & $4160 / 3015$ & $605 / 435$ & $1991 / 1836$ & $1110 / 961$ & 35241 & 71.4 \\
\hline Volokonovsk & $3509 / 2581$ & $950 / 514$ & $3125 / 2019$ & $1087 / 779$ & 30823 & 67.9 \\
\hline Valuisk & $7428 / 1636$ & $1185 / 216$ & $4387 / 1528$ & $2162 / 538$ & 3088 & 13.9 \\
\hline Total & $33647 / 22840$ & $7666 / 5143$ & $22309 / 17906$ & $9443 / 6826$ & 203095 & 61.8 \\
\hline
\end{tabular}

for monitoring the status of soils and soil cover, to update the data of cadastral land valuation, and to take management decisions for the rational use of land resources and sustainable development of the area of the southern part of the Central Russian Upland [1].

The ArcGIS program enables us to use the methods of comparative analysis of different-time large-scale soil maps with high accuracy as an innovative supplement to the system of soil-ecological monitoring.

\section{CONCLUSIONS}

(1) The period prior to the first soil survey was characterized by mean annual temperatures below the average, and the hydrothermal coefficient varied from 1.1 to 0.8 in the north-south direction. In the period between the first and second soil surveys, there was a rise in precipitation, and the hydrothermal coefficient increased from 1.1 to 1.33 . The humidification was the greatest in Shebekinsk, Korochansk, Valuisk, and
Volokonovsk districts, where the HTC increased by $0.25-0.37$ as compared to the previous 20-year-lomg survey period.

(2) The soil cover in the studied area is in general resistant to short-term climatic fluctuations, which is proved by the GIS analysis of soil areas unchanged over the period of the surveys. The area of these soils is 328885 ha $(61.5 \%)$. The transformed soil subtypes comprise one third of soil areas in the studied region (125790 ha or $38.5 \%$ ). The area of changed soils was the largest in Valuisk district (19080 ha) and the smallest in Starooskol'sk district (10020 ha).

(3) Under the conditions of cyclogenesis, the depth of effervescence line in chernozems varies, which results in a change in the taxonomic position of soils at the subtype level. These transformations may be considered as a response of the soil cover to short-period climatic fluctuations. This morphological feature is the most variable in typical chernozem in Korochansk, 
Novooskol'sk, Volokonovsk, and Valuisk districts in the south of the Central Russian Upland.

(4) The area of transformed soils is the greatest on the northern slopes ( 33647 ha in general) and is the smallest on the eastern slopes (7666 ha).

\section{REFERENCES}

1. Yu. G. Chendev, N. S. Kukharuk, A. G. Narozhnyaya, L. G. Smirnova, S. A. Kukharuk, G. V. Smirnov, I. Timokhov, and A. I. Timoshenko, RF Patent No. 2018620143, (2018).

2. G. S. Bazykina and O. S. Boiko, "Impact of weather anomalies in recent decades on the water regime of typical chernozems of the reserved steppe area in Kursk oblast," Eurasian Soil Sci. 41, 731-743 (2008).

3. V. F. Val'kov, K. Sh. Kazeev, and S. I. Kolesnikov, "Carbonaceous soils: genetic and ecological aspects," Gruntoznavstvo 6 (1-2), 11-18 (2005).

4. A. N. Gennadiev, Soils and Time: Models of Development (Moscow State Univ., Moscow, 1990), pp. 136-137.

5. G. V. Gruza and E. Ya. Ran'kova, "Climate oscillations and changes over Russia,” Izv. Atmos. Ocean. Phys. 39, 145-162 (2003).

6. A Report on the Climate Conditions in the Russian Federation in 2011 (Rosgidromet, Moscow, 2012) [in Russian].

7. A Report on the Climate Conditions in the Russian Federation in 2016 (Rosgidromet, Moscow, 2017) [in Russian].

8. Climate Change 2001: Synthesis Report. Contribution of Working Groups I, II, and III to the Third Assessment Report of the Intergovernmental Panel on Climate Change, Ed. by R. T. Watson (Cambridge University Press, Cambridge, 2001; World Meteorological Organization, Moscow, 2001).

9. L. V. Klimenko, "Air temperature fluctuations in the southern part of European territory of the Soviet Union in 1891-1990," Vestn. Mosk. Gos. Univ., Ser. 5: Geogr., No. 1, 25-30 (1992).

10. Yu. A. Izrael, G. V. Gruza, V. M. Katsov, and V. P. Meleshko, "Global climate changes. The role of anthropogenic impacts," Russ. Meteorol. Hydrol., No. 5, 1-12 (2001).

11. S. V. Ovechkin and G. S. Bazykina, "The carbonate profile and water regime of migrational-mycelial chernozems in different ecosystems of Kursk oblast," Eurasian Soil Sci. 44, 1352-1363 (2011).

12. Yu. P. Perevedentsev, F. V. Gogol', E. P. Naumov, and K. M. Shantalinskii, "Global and regional climate change at the turn of 20th and 21st century," Vestn. Voronezh. Gos. Univ., Ser. Geogr., Geoekol., No. 2, 5-12 (2007).

13. Soils and Vegetation in the South of the Central Russian Upland under Conditions of Climate Change, Ed. by Yu. G. Chendev and M. G. Lebedeva (Konstanta, Belgorod, 2016) [in Russian].

14. V. N. Razuvaev and M. Z. Shaimardanov, Global Climate Change (Modus K-Eterna, Moscow, 2005) [in Russian].

15. E. V. Rogozhnikova, Candidate's Dissertation in Biology (Moscow, 2010).

16. L. G. Smirnova, N. S. Kukharuk, and Yu. G. Chendev, "Soil cover in the southern forest-steppe of the Central Russian Upland against the background of centennial climate fluctuations," Eurasian Soil Sci. 49, 721-729 (2016).

17. O. S. Khokhlova, Doctoral Dissertation in Geography (Moscow, 2008).

18. Yu. G. Chendev and A. N. Petin, "Climate change in the 20th century and its impact on the soil cover," in Proceedings of International Scientific Conf. "Climate Change, Soils, and Environment," Belgorod, September 16-19, 2009 (Konstanta, Belgorod, 2009), pp. 147-155.

Translated by I. Bel'chenko 